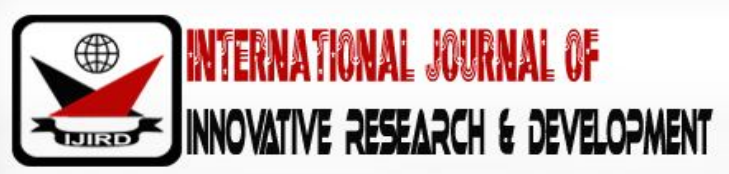

ISSN 2278 - 0211 (Online)

\section{Project Implementation Process and Performance of Indigenous Chicken Projects Sponsored by Agricultural Sector Development Support Programme, Machakos County, Kenya}

\author{
Nduthu P.W \\ Ph.D. Student, School of Open and Distance Learning, University of Nairobi, Kenya \\ Dr. Omutoko, L. 0 \\ Senior lecturer, School of Open and Distance Learning, University of Nairobi, Kenya \\ Dr. Mulwa, A. S \\ Lecturer, School of Open and Distance Learning, University of Nairobi, Kenya
}

\begin{abstract}
:
Indigenous chicken projects are important for food security and poverty alleviation but the performance has remained poor. Due to that there is need to identify the cause of poor performance. Therefore this paper calls for a paradigm shift in implementation of indigenous chicken projects for better Performance. It is based on a study carried out in Machakos County of Kenya focusing on the influence of project implementation process on performance of indigenous chicken projects. The study addressed project implementation process from the perspective of availability of indigenous chicken plans, usage of indigenous chicken resources and execution of indigenous chicken activities and the manner in which the process is followed. The study was guided by pragmatism paradigm using mixed method research design. The target population was 80 indigenous chicken projects which were supported by Agricultural Sector Development Support Programme. The sample of 40 projects was selected through multi-stage sampling where 146 respondents were selected. Questionnaire and interview guide were used to collect data from project implementers and 10 partnering stakeholders respectively. The data was analysed descriptively using means and standard deviation. For inferential analysis, Pearson's product moment correlation and F-test were used. The descriptive statistics realized a mean score of 3.4250 and a standard deviation of 0.41705 . The descriptive statistics results pointed out that the indigenous chicken project implementers agreed to theproject being planned, the resources being mobilized and lastly execution done. However inferential analysis indicated that project implementation process influenced performance of indigenous chicken projects statistically significantly with a moderate positive correlation where $r=0.344$ and at level of significance $p=0.000 \varangle 0.05$. Likewise $r^{2}=0.118$ was realized showing that project implementation process contributed11.8\% to performance of indigenous chicken projects.Since project implementation process only contributed $11.8 \%$ to performance of projects, there is need to do further research on influence of other indicators of project implementation process apart from availability of plans, usage of resource and execution of indigenous chicken activities on performance of projects. The study recommends that plans should be available as part of project implementation process so as to improve performance.
\end{abstract}

Keywords: Performance of projects, project implementation process, indigenous chicken projects

\section{Introduction}

The importance of Indigenous chicken projects for food security and poverty alleviation in developing countries (FAO, 2014; Moreki, Dikeme \& Poroga, 2010; Muchadeyi, et al., 2007)is attributed to 90 percent of the world population keeping Indigenous Chicken as compared to the exotic poultry (Padhi, 2016; Okeno, Kahi \& Peters, 2012). The preference of keeping indigenous chicken is due to their hardness in weatheradaptation, disease resistance, while as their plumage colour protects them against predators and further they are easy to market (Bett, Musyoka, Peters \& Bokelmann, 2012). Similarly Bett, et al., (2014) indicated that to start indigenous chicken project, requires a low startup capital unlike exotic poultry projects. However Sarkar and Golam (2009) asserted that in a bid to improve performance of Indigenous Chicken projects, there should be changes in traditional management practises.

Different studies have identified the cause of poor performance of indigenous chicken projects. Study by Dinka, Chala, Dawo, Bekana, \& Leta (2010). indicated poor planning in an indigenous chicken project by ministry of Agriculture to cause 
poor performance. Further Siyaya and Masaku (2013) in Swaziland indicated that lack of resources and planningto cause poor performance in Indigenous Chicken projects. Based on previous studies, planning and resources have been shown to cause poor performance of indigenous chicken. Therefore planning and resources forms the indicators of project implementation process which is grounded by implementation theory.

Implementation theory indicates that given a goal of any project, the implementation process should be designed in such a manner that predicted outcomes coincide with the desirable performance (Corchon, 2008). Further Maskin and Sj'str6m, (2002) posit that the development of implementation theory is meant to address the failure of most project implementation processes to improve performances that satisfy a given criteria which are procedural tool and allocation rule.Therefore this study sought to investigate the influence of project implementation process on performance of indigenous chicken projects in Machakos County, Kenya.

\subsection{Statement of the Problem}

Indigenous chicken projects are profitable and hence important for employment, food security and poverty alleviation in developing countries (Ayieko, Bett \& Kabuage, 2014; Moreki, Dikeme \& Poroga, 2010). Though Indigenous Chicken products demand by consumers has increased, indigenous chicken projects continue to perform poorly due to poor project management practises thereby reducing their contribution to food security and rural income (Magothe, Okeno, muhuyi \& kahi, 2012). Studies have identified poor project implementation process to cause poor performance of indigenous chicken projects. HoweverDinka, et al., (2010) indicated poor planning in a project by ministry of Agriculture to cause poor performance of indigenous chicken projects. Likewisea study by Siyaya and Masaku (2013) in Swaziland asserted that lack of resources and planningto cause poor performance in Indigenous Chicken projects during implementation. Further Tabassum, et al., (2014) in Bangladesh and Sathe (2012) identified that timely availability of resources to improve performance of indigenous chicken projects during implementation. Similarly Okeno, et al., (2012) results revealed poor planning and lack of breeding program to supply resources like quality breeding stock to cause poor performance of indigenous chicken during execution. From studies done in Machakos by Nduthu (2015), Mailu et al., (2014) and Mutombo (2014) none has been able to address the performance of indigenous chicken projects by using planning, resource mobilizationand execution as indicators of project implementation process to improve performance of indigenous chicken projects. Based on the above studies there is a gap in implementation process. Hence a study was done to investigate influence of project implementation process on performance of indigenous chicken projects.

\subsection{Objective of the Study}

The research objectiveof the study is to investigatethe influence of project implementation process on performance of indigenous chicken projects in Machakos County, Kenya.

\subsection{Research Hypothesis}

The research hypothesis tested was:

- $\mathrm{H}_{0}$ : Project implementation process has no significant influence on performance of indigenous chicken project in Machakos County, Kenya.

\section{Literature Review}

Poor performance of Indigenous Chicken projects has been shown by global statistics where the indigenous chicken meat produced is only 30\% of all the meat consumed (Food and Agriculture Organisation (FAO), 2012) due to poor management. Further global poultry meat output which though expected to amount to 106.4 million tonnes by 2013, showed growth to slow down annually since 2010 from around 4.5 per cent to 1.8 per cent (FAO, 2013). Likewise in Indian Continent Indigenous chicken projects has shown poor performance as they contribute about $19.75 \%$ and $25.06 \%$ of total meat and egg produced respectively (Dutta, Saiful, Islam \& Kabir (2013). The same has been replicated in Africa, Kenya and Machakos where meat output was 2.7millon tonnes, 22,700tonnes and 862 tonnes respectively (Global poultry trends, 2014). Due to that there is need for an intervention by identifying the implementation process so as to improve performance of indigenous chicken projects.

Project implementation process shows a typical cycle of project life where a project is structured on what is to be done, how to do it, doing it and closing (Patzak 2009). Similarly Pinto and Slevin (1989) showed project implementation process as a guide of "what do we want to do as plans; how do we want to do it through use of resources; then we do it by executing plans". Project implementation process would influencethe execution of indigenous chicken projects as it provides project plans, specifications, and the original project feasibility (Project Management Method, 2015).The views of Patzak (2009) and Pinto \& Slevin (1989) in project implementation process has a relationship with literature reviewed globally of indigenous chicken programmes/ projects showing areas causing poor performance as poor planning, lack of timely availability of resources during execution.

Implementation process is required in achieving performance ofprojects (Javed, Mahmood \& Sulaiman(2012). Findings by Javed et al., (2012) indicates that planning, resources, people are required in achieving performance which 
grounds the fact that to improve performance of indigenous chicken projects, planning, resources, utilization of resources which is done in execution should be ensured.Further Nganga and Amuhaya (2013) study on management in implementation of government sponsored projects in Kenya indicated planning to play a big role in successful execution. Likewise Siyaya and Masuku (2013) indicated poor planning during implementation of project to cause poor performance of indigenous chicken projects.From the literature reviewed, no study has been done showing how project implementation process influence performance of indigenous chicken projects in Machakos County.

\subsection{Theoretical Framework}

This study of influence of project implementation process on performance of indigenous chicken projects in Machakos County is grounded by performance theory and implementation theory.

\subsection{Performance theory}

Performance theory came to solve project implementation fiascos and management practices where it identified that all projects are not the same and full performance involves a level of competence that produces project implementation processes, though measures of performance are to be discovered in each project (Bauman, 1986). Similarly Kihoro and Waiganjo (2015) indicated competence in implementation is required to influence performance.Further Bauman (1986) indicated that performance theory should focus on context of project. Likewise on context factors Woollett (2000) and Campbell, et al., (1993) indicated that project practises should come up with a way of achieving performance and highlighted that practises are different with different project. However Costello, (2008) asserted that performance theory does not look at action itself but by judgmental and evaluative processes achieved through implementation process. Moreover, advances have been made in specifying major project implementation process associated with project performance. Study by Reilly (2007) showed performance to be measured by customer focus, leadership, processes, and values. These concepts by Reilly (2007) are linked to Customer focus to implementers' satisfaction, processes to activity delivery time and value to production numbers.

\subsection{Implementation theory}

Implementation theory was developed to solve the implementation problem. This sentiment was backed by Maskin and Sj'str6m, (2002) where they indicated that the development of implementation theory was to address the failure of most project implementation processes to achieve performance. Likewise study by Kakhbod, (2013) and Maskin and Sj'str6m (2002) indicated that implementation theory provides a mechanism where resources are allocated among project stakeholders.Similarly study by Hagel and Brown (2008) indicated that to improve performance of projects, rather than "push", the new approach that focus on "pull" should be used by stakeholders as it creates platforms that help people to mobilize appropriate resources to implement Indigenous Chicken projects using the allocation rule as indicated in the implementation theory. Further Baliga and Sjöström (2007) asserted that implementation theory comes up with procedures which are used to bring about the performance of projects.

This is echoed during planning wherepractical thought brings action which is structured by plans as a conceptual tool in implementation theory (Bratman, 2015). Following the argument it has been identified that for implementation theory to influence performance it should have mechanism with procedures, allocation rule, stakeholders which are linked to project planning, project resource mobilization.Likewise Koskela and Howell (2008) indicate that execution comes in translating indigenous chicken project plans to action. Further Koskela (2000) asserts that during execution if availability of these resources is uncertain, it may lead to uncertainties in performance of Indigenous Chicken project. The uncertainty of resources will be solved through the implementation theory by use of conceptual tools and allocation rule hence successive execution of performance of Indigenous Chicken project. 
Independent variable

Project implementation process

\section{Dependent variable}

\section{Project planning \\ - Participation in plan development \\ - Availability of indigenous chicken plans}

\section{Project resource mobilization}

- Avallability of indigenous chicken resources

- Usage of indigenous chicken resources.

\section{Project execution}

- Group executing plan

- Execution of indigenous chicken activities

Figure 1: Conceptual framework

\section{Methodology}

The study research design was mixed method which was guided by pragmatism paradigm. The target population was the 80 indigenous chicken projects supported by Agricultural sector Development Support Programme (ASDSP) and 10 stakeholder organizations namely Kenya Agriculture Livestock Research Organization (KALRO), Social Services, Kenya Poultry Farmers Association (KEPOFA), directorate of Livestock and veterinary, World vision, Hand in Hand (HiH), Anglican Development Services (ADS) and United States Aid in Development (USAID). Multi-stage sampling technique was used to select respondents through three sampling stages hence giving respondents consistently equal chances of being chosen in a step by step procedure starting with selection of 80 indigenous chicken projects sponsored by ASDSPat the first stage, followed by selection of 40 indigenous chicken projects in the Sub-Counties at the second stage and finally selection of 146 respondents from the sampled projects based on sampling procedures of Sekaran (2003). To collect qualitative data in the study, 10 managers of the 10 organizations that are partnering with Indigenous Chicken projects sponsored by Agricultural Sector Development Support programme was purposively selected and interviewed with interview guide.

The validity of the research instruments was done with use of expert opinion from three organizations partnering with ASDSP sponsored indigenous chicken projects in a focus group dialogue where the precision, importance and correctness of the objects was done. The reliability was tested with the use of split half where the results gave a Cronbach (Alpha) reliability coefficient of 0.788 showing that the responses had an internal consistency. Data was collected by use of 146 openclosed ended question Likert scale items questionnaires and 10 interview guide which had open ended questions.Data was analysed through use of descriptive and inferential statistics where under descriptive statistics, means, standard deviation was used whereas under inferential statistics, Pearson Product Moment Correlation coefficient and F test was used to test for hypothesis. To analysis the influence of the project implementation process on performance of indigenous chicken projects, a model was formulated where y $=\beta_{0}+\beta_{1}\left(X_{1}\right)+\varepsilon$; where $Y=$ Project performance, $X_{1}=$ Project implementation process; $\beta_{2}=$ regression coefficient of the

\section{Results and findings}

The questionnaires were administered to 146 indigenous chicken project implementers but only 138 were returned which is a response rate of $95 \%$.

\subsection{Respondents Demographics}

The respondents demographics was reported in terms of gender, age, education levels, yearly income levels and average number of eggs laid per hen per batch. Results revealed that the majority of the respondents were female at $61.6 \%$ while males were $38.4 \%$. This result indicated that mostly indigenous chicken is kept by women which could be attributed to low startup capital of the indigenous chicken projects (Bett, et al., 2014) taking that most rural women are not in formal employment. However majority of the respondents were above $45 y$ ears at $40.6 \%$ while as the ages of 18-35years and 3645years were each at $29.7 \%$. This results revealed that mostly the indigenous chicken project implementers above $45 y e a r s$ knows that they cannot get formal employment hence they have undertakenkeeping of indigenous chicken asan income generating entreprise as indicated by studies that indigenous chicken are important for poverty alleviation (FAO, 2014; Moreki, Dikeme \& Poroga, 2010; Muchadeyi, et al., 2007).

Likewise majority of the respondents had secondary education at $56.5 \%$, followed by primary education at $31.9 \%$, then post-secondary education at $9.4 \%$ and lastly non-formal at $2.2 \%$. Further the result on education level has an indication that the project implementers understood better the management practises as compared to the ones who have no formal 
education as they have the competence (Kihoro \&Waiganjo, 2015; Bauman, 1986). Similarly majority of the respondents' yearly income levels was below ksh10000 at 45.7\%, followed by ksh10001-20000at 38.4\%, ksh20001-30000 at $8.0 \%$, ksh30001-40000 at 5.8\%, ksh40001-50000 at 1.4\% and above ksh50000 at 0.7\%. This result indicates that not all the project implementers have taken up the management practices hence low improved performance leading to the majority getting Ksh10000 and below.On eggs laid, the majority of the respondents at 50\% had their hens laying 9-12eggs, 37\% had their hen laying 13-16eggs, $8.7 \%$ and $4.3 \%$ had their hen laying 5-8eggs and 1-4eggs respectively. This result indicated that the majority of project implementers had taken up good management in taking care of eggs, by having laying places which shows a step to improved performance.

\subsection{Performance of Indigenous Chicken Project}

Performance of indigenous chicken projects was measured by increased production numbers, timeliness of activity delivery and level of project implementers' satisfactionas identified that performance should judgmental and evaluative (Costello, 2008; Reilly, 2007). To measure the indicators of performance, Likert scale items were formulated and analysed using descriptive statistics. Under increased production numbers the respondents agreed that they got at least get 13 eggs where they incubated 12, but were neutral that on average 10 chickshatched with a mean score of 3.5435, 3.5362 and 3.3116 respectively. This result indicates that the project implementers undertook the management practices on breeding. Further the project implementers were neutral that all their chicks grew to mature hens with a mean score of 3.1232. This result revealed that the performance of indigenous chicken improved as most project implementers used brooders to brood their chicks and fed them with chick mash. Similarly on timely activity delivery, the project implementers agreed that they got the plan of activities early, formed groups which facilitatedearly trainings with a mean score of 3.7971 and acquired their chick brooders earlywith mean score of 3.7029 as asserted by Tabassum, et al., (2014) where they indicated that the resources should be timely acquired. This result revealed that the project management was delivered on time; the project implementers undertook the management practices on time hence improving performance of indigenous chicken.

Lastly on level of satisfaction, the indigenous chicken project implementers agreed that the management practises deliverymethod was good and was easily implementable with a mean score of 4.0217 and 3.9058 respectively. However they agreed that the equipment they were using for rearing chicken like brooders, drinkers, feeders were appropriate, affordable and the right size as required with a mean score of 3.6739, 3.65 and 3.7681 respectively. This led to the indigenous chicken project implementers undertaking the management practices and hence improved performance of indigenous chicken projects. This resulton performance of projects was backed by the stakeholders partnering with the indigenous chicken project implementers where they indicated that the performance improved. Similarly the stakeholders agreed that the indigenous chicken project implementers were satisfied where they ranged the level of performance between fairly well to good.

\subsection{Project Implementation Process}

Project implementation process was measured with planning, resource mobilization and execution of activities, which was in line with Javed, et al., 2012 study where he identified that planning, resources and people are required to achieve performance. To measure the indicators of project implementation process, Likert scale items were formulated and analysed using descriptive statistics. Under planning the indigenous chicken project implementers agreed that training need were participatory and voluntarily done with a mean score of 4.1884 and 3.7391 respectively. Similarly the project implementers agreed that they chose the areas of training which had a mean score of 3.4638.The result has shown that all what was to be executed was planned. These results are in line with the study by Baliga and Sjöström (2007) that asserted plans give procedures. Further the project implementers agreed that the plan of activities showed all what the project should implement from group formation, trainings, linkage to stakeholders and taking the implementers to tour which had a mean score of $3.7917,3.5435$ and 3.5725 respectively.

Likewise on resource mobilization, the indigenous chicken project implementers agreed that drugs are packed in quantities that are affordable with a mean score of 3.4145. Similarly the project implementers agreed that they do not have cool boxes to carry New Castle Vaccines with a mean score of 3.5217 while as they were neutral on credible shops selling vaccines, drugs, brooders near them with a mean score of 2.9928 . The project implementers agreed they vaccinate their chicken with a mean score 3.7971 but stated that at times the 100 doses of the vaccine is not available with a mean score of 3.4275. But they were neutral on putting their chicks in the brooders with a mean score of 2.8043 .

Similarly onproject execution the project implementers agreed that they support one another to buy equipment for rearing chicken and do group vaccinations with a mean score of 3.5000 and 3.5942 respectively.This result is echoed by Hagel and Brown (2008) where they asserted that stakeholders' uses pull approach to mobilize for resources. The project implementers agreed that they do selection of the best breeds, take care of eggs and had chicken house, but identified that the chicken houses are not constructed appropriately with mean score of 4.0870, 3.9203 and 4.2464. These results are in agreement with the stakeholders responses where they indicated that the plans were available as 5 of the stakeholders were involved in development of the indigenous chicken plan with the management activities. Likewise 5 of the stakeholders agreed that the resources were used as they gave resources like New castle Disease Vaccine, chicks, paraffin incubators and a feed miller to make chicken feeds. This is in agreement withstudy by Okeno, et al., (2012) where they indicated that planning and 
availability of resources like breeding stocks to improve performance. Lastly on execution all the 10 stakeholders agreed that the respondents implemented the indigenous chicken management activities like constructing of poultry houses, management of mother hen, eggs and chicks though most of them did it partially. The results of the stakeholders on undertaking of indigenous chicken activities is backed by study by Koskela and Howell, (2008) where they indicate that during execution project plans are translated to actions.

\subsection{Project implementation process and performance of indigenous chicken projects}

Though all the respondents agreed that they undertook project implementation process, to get the influence that it had in performance of indigenous chicken, a relationship was tested using correlation and the results presented in table 1.

\begin{tabular}{|c|c|c|c|c|}
\hline \multicolumn{2}{|c|}{ Indicators } & $\begin{array}{c}\text { Production } \\
\text { Numbers }\end{array}$ & $\begin{array}{c}\text { Timeliness activity } \\
\text { delivery }\end{array}$ & $\begin{array}{c}\text { Implementers } \\
\text { satisfaction }\end{array}$ \\
\hline \multirow{3}{*}{$\begin{array}{c}\text { Pearson } \\
\text { correlation }\end{array}$} & Performance & 1.000 & 1.000 & 1.000 \\
\cline { 2 - 5 } & Availability of indigenous chicken plans & .207 & .024 & .406 \\
\cline { 2 - 5 } & Usage indigenous chicken resources & .090 & .077 & .193 \\
\cline { 2 - 5 } Sig. (1 tail) & Execution of indigenous chicken activities & .184 & .129 & .000 \\
\cline { 2 - 5 } & Availability of indigenous chicken plans & .007 & .392 & .012 \\
\cline { 2 - 5 } & Usage indigenous chicken resources & .146 & .184 & .000 \\
\cline { 2 - 6 } & Execution of indigenous chicken activities & .016 & 138 & 138 \\
\cline { 2 - 6 } & Availability of indigenous chicken plans & 138 & 138 & 138 \\
\cline { 2 - 6 } & Usage indigenous chicken resources & 138 & 138 & 138 \\
\cline { 2 - 6 } & Execution of indigenous chicken activities & 138 & 138 & 138 \\
\hline
\end{tabular}

Table 1: Inferential Relationship between Project Implementation Process Indicators

And Performance of Indigenous Chicken Projects Indicators

Result of table 1 revealed that availability of plans andexecution of indigenous chicken activities had a weak positive correlation with production numbers in performance of indigenous chicken projects with $r=0.207$ and $r=0.184$ respectively, These results indicated that the production numbers of indigenous chicken were not maximally achieved as the execution of activities was inadequately done and the plans were thinly followed during execution. Usage of resources had no correlation with production numbers in performance of indigenous chicken projects with $r=0.090$ which indicated that usage of the resources did not influence production of indigenous chicken. Further the results showed that availability of plans and usage of resources had no correlation with timeliness of activity delivery with $r=0.024$ and $r=0.077$ respectively. These results revealed that plans were not availed on time and resources were not timely used which could have influenced the performance of indigenous chicken projects.This result is in agreement with the study of Tabassum, et al., (2014) and Sathe (2012) where they indicated that lack of timely availability of resources influences performance of indigenous chicken projects.

Execution of activities had a weak positive correlation with timeliness of activity delivery with $\mathrm{r}=0.129$. The weak positive correlation of execution on performance of indigenous chicken projects confirmed that only few indigenous chicken activities were done on time. Lastly availability of plans and execution of activities had a moderate positive correlation with satisfaction of project implementers with $r=0.406$ and $r=0.470$ respectively. These results indicated that indigenous chicken project implementers' were satisfied with the activities of the plans and the activities they were to execute. Usage of resources had a weak positive correlation with satisfaction of project implementers in performance of indigenous chicken projects where $r=0.193$. This result revealed that respondents were not satisfied with the resources they were to use. To further investigate the strength of project implementation process indicators on performance of indigenous chicken projects regression analysis was conducted where a regression model was developed. The regression model used denoted $\mathrm{Y}=$ Performance of indigenous chicken projects;

$\mathrm{X}_{1}=$ Availability of plans;

$\mathrm{X}_{2}=$ Usage of resources;

$\mathrm{X}_{3}=$ execution of indigenous chicken activities. 


\begin{tabular}{|c|c|c|c|c|c|c|c|c|c|}
\hline \multirow[t]{2}{*}{ Model } & \multirow[t]{2}{*}{$\mathbf{R}$} & \multirow{2}{*}{$\begin{array}{c}\text { R } \\
\text { Square }\end{array}$} & \multirow{2}{*}{$\begin{array}{l}\text { Adjusted } \\
\text { R Square }\end{array}$} & \multirow{2}{*}{$\begin{array}{l}\text { Std. Error } \\
\text { of the } \\
\text { Estimate }\end{array}$} & \multicolumn{5}{|c|}{ Change Statistics } \\
\hline & & & & & $\begin{array}{c}\text { R Square } \\
\text { Change }\end{array}$ & F Change & df1 & df2 & $\begin{array}{c}\text { Sig. F } \\
\text { Change }\end{array}$ \\
\hline 1 & $.344 a$ & .118 & .098 & .37245 & .118 & 5.983 & 3 & 134 & .001 \\
\hline \multirow[t]{2}{*}{ Mode } & & & $\begin{array}{l}\text { Sum of } \\
\text { Squares }\end{array}$ & \multicolumn{2}{|l|}{$\mathrm{df}$} & Mean Square & \multicolumn{2}{|l|}{$\mathrm{F}$} & Sig. \\
\hline & & Regression & 2.490 & 3 & \multicolumn{2}{|c|}{.830} & \multicolumn{2}{|l|}{5.983} & $.001 \mathrm{~b}$ \\
\hline \multirow[t]{2}{*}{1} & & Residual & 18.588 & \multirow{2}{*}{\multicolumn{2}{|c|}{$\begin{array}{l}134 \\
137\end{array}$}} & \multirow[t]{2}{*}{.139} & & & \\
\hline & & Total & 21.078 & & & & & & \\
\hline
\end{tabular}

Table 2: Regression Results of the Influence of Project Implementation Process on Performance of Indigenous Chicken Projects

\begin{tabular}{|c|c|c|c|c|c|c|c|}
\hline & \multicolumn{2}{|c|}{$\begin{array}{c}\text { Unstandardized } \\
\text { Coefficients }\end{array}$} & $\begin{array}{c}\text { Standardized } \\
\text { Coefficients }\end{array}$ & $\mathbf{t}$ & Sig. & \multicolumn{2}{c|}{$\begin{array}{c}\text { 95.0\% Confidence } \\
\text { Interval for B }\end{array}$} \\
\hline & $\mathrm{B}$ & Std. Error & Beta & & & $\begin{array}{c}\text { Lower } \\
\text { Bound }\end{array}$ & $\begin{array}{c}\text { Upper } \\
\text { Bound }\end{array}$ \\
\hline & 2.289 & .298 & & 7.687 & .000 & 1.700 & 2.877 \\
\hline $\begin{array}{c}\text { Availability of indigenous } \\
\text { chicken plans }\end{array}$ & .242 & .081 & .281 & 3.001 & .003 & .083 & .402 \\
\hline $\begin{array}{c}\text { Usage indigenous chicken } \\
\text { resources }\end{array}$ & -.025 & .094 & -.027 & -.266 & .790 & -.210 & .160 \\
\hline $\begin{array}{c}\text { Execution of indigenous } \\
\text { chicken activities }\end{array}$ & .117 & .076 & .143 & 1.526 & .129 & -.035 & .268 \\
\hline $\begin{array}{c}\text { (Constant) } \\
\text { Project implementation } \\
\text { process }\end{array}$ & 2.042 & .308 & & 6.229 & .000 & 1.315 & 2.524 \\
\hline
\end{tabular}

Table 3

$\mathrm{Y}=2.289+0.281 \mathrm{X}_{1}-0.027 \mathrm{X}_{2}+0.143 \mathrm{X}_{3}$

This indicated that it is a moderate model for predicting performance of indigenous chicken projects. However, the value of $\mathrm{r}^{2}$ is 0.118 , which revealed that the indicators of project implementation process would contribute 11.8percent of performance of indigenous chicken projects. Further, results indicates that, out of the total contribution made to project implementation process, availability of plans is the most important performance factor as it contributed a beta value of 0.281 as compared to -0.027 and 0.143 , for usage of resources and execution of indigenous chicken activities respectively. The negative beta value in resource usage of resources indicates that the beta factor of -0.027 indicates that a unit increase in resource used caused a decrease in performance of indigenous chicken projects of $2.7 \%$.

Similarly the hypothesis was tested using the following regression model:

Performance of indigenous chicken $=f$ ( project implementation process of indigenous chicken)

$\mathrm{Y}=\beta_{0}+\beta_{4} \times \mathrm{X}_{4}+\varepsilon ; \mathrm{Y}=$ Performance of indigenous chicken; $\mathrm{X}_{4}=$ Project implementation process; $\beta_{0}=$ Constant term; $\beta_{1}=$ coefficient of project implementation process; $\varepsilon=$ Error term.

On substituting $Y=\beta_{0}+\beta_{4} \times X_{4}+\varepsilon$ then $Y=2.042+0.421 X_{4}$

The result indicated that a unit percent (\%) increase in project implementation process $\left(\mathrm{X}_{4}\right)$ would bring about an increase of $42.1 \%$ in performance of projects (y). Further results revealed that a level of significance of p-value of 0.000 and $F$ $(1,136)=4.530$ were realized where the correlation was significant at $p<0.05$.This result was used in identifying whether the null hypothesisstated "Project implementation process has no significant influence on performance of projects", would be rejected or not rejected. Hence the null hypothesis that stated "Project implementation process has no significant influence on performance of projects" was rejected as the p-value was 0.000. A correlation therefore exists between project implementation process and performance of project as the null hypothesis was rejected.

\section{Conclusion}

The objective of this study was to determine the influence of project implementation process on performance of indigenous chicken projects sponsored by Agricultural Sector Development Support Programme in Machakos County, Kenya. The alternate hypothesis that project implementation process has significant influence on performance of indigenous chicken projects in Machakos County Kenya was not rejected showing that project implementation process influenced performance of indigenous chicken projects. This conclusion is drawn from the hypothesis of this study which revealed that project implementation process significantly influenced performance of indigenous chicken projects. The study supports the use of 
project implementation process during implementation as it ensures that the plans are availed, resources used according to plan and the activities from plans are executed which in turn improves performance of indigenous chicken projects.

Lastly this study recommends that every project implementer to use project implementation process in order to achieve performance of indigenous chicken projects. Further research should be done of project implementation process but with more indicators together with availability of plans, usage of resources and execution of indigenous chicken activities as those indicators showed that the contribution to performance of indigenous chicken projects was $11.8 \%$.

\section{References}

i. Ayieko, D. M. O, Bett, E. K. \& Kabuage, L. W. (2014). Profitability of Indigenous Chicken: The Case of Producers in Makueni County. Journal of Economics and Sustainable Development Kenya, 5(11), 16-24.

ii. Baliga, S. \& Sjöström, T. (2007). Mechanism Design: Recent Developments. L. Blume and S. Durlauf (eds.). The New Palgrave Dictionary of Economics, 2nd Edition, London: McMillan.

iii. Bett, R. C. Bhuiyan, A. K. F. H., Khan, M. S., Silva, G. L. L. P., Thuy, Le Thi, Sarker, S. C. Abeykoon, M. N. D., Nguyen, Thi T. H., Sadef, S., Kariuki, E., Baltenweck, I. P. J., Mwai, O. \&lbrahim, M. N. M. (2014). Indigenous chicken production in the South and South East Asia. Livestock Research for Rural Development; 26 (12) 2014.

iv. Bett, H. K., Musyoka, M. P., Peters, K. J. \& Bokelmann, W. (2012). Demand for Meat in the Rural and Urban Areas of Kenya: A Focus on the Indigenous Chicken. Economics Research International. Volume, Article ID 401472, 10 pages.

v. Bratman, M. E. (2015). Précis of Shared Agency: A Planning Theory of Acting Together. Journal of Social Ontology; 1(1): 1-5.

vi. Campbell, J. P., McCloy, R. A., Oppler, S. H., \& Sager, C. E. (1993). A theory of performance. In E. Schmitt, W. C. Borman, \& Associates (Eds.), Personnel selection in organizations; 35-70. San Francisco: Jossey-Bass.

vii. Corchon, L. (2008). The Theory of Implementation. The Encyclopedia of Complex exit strategy and System Science, Berlin: Springer.

viii. Costello, A. (2008). Getting results: The six disciplines for performance-based project management. Riverwoods, Ill: $\mathrm{CCH}$.

ix. Delgado, C. L. (2005). Rising demand for meat and milk in developing countries: implications for grasslands-based livestock production. In: D.A. McGilloway (ed.). Grassland: a global resource. Proceedings of the twentieth International Grassland Congress, 26-30 June 2005, Dublin, Ireland. Wagingen: Wagingen Academic Publishers, pp. 29-39.

x. Dinka, H., Chala, R, Dawo, F., Bekana, E.,\& Leta S. (2010). Major constraints and health management of village poultry production in Rift Valley of Oromia, Ethiopia. Am.-Eurasian J. Agric. Environ. Sci. 2010; 9:529-533.

xi. Dutta, R. K, Saiful, M., Islam, S. I. \& Kabir, M. A. (2013). Production Performance of Indigenous Chicken (Gallus domesticus L.) in Some Selected Areas of Rajshahi, Bangladesh. American Journal of Experimental Agriculture, 3(2): 308-323.

xii. Food and Agriculture Organisation (2014). Animal production and health: Decision tools for family poultry development. Published by the food and agriculture organization of the united nations

xiii. Food and Agriculture Organization (2013). Global poultry trend: Poultry site.

xiv. Food and Agriculture Organisation, (2012). Small livestock, big impact. Retrieved on 27/4/2012 from www.ilriclippings.wordpress.com

xv. Global poultry trends (2014). Steady Rise in Chicken Meat Output for Africa and Oceania. Poultry site.

xvi. Hagel, J. and Brown, J. S. (2008). From Push to Pull: Emerging Models for Mobilizing Resources. Journal of Service Science; 1(1), 93-111.

xvii. Hatcher, L. (2013). Advanced Statistics in Research: Reading, Understanding, and Writing Up Data Analysis Results. Publisher: Shadow Finch Media LLC (January 7, 2013). ISBN13: 978-0985867003

xviii. Javed, M. S., Mahmood, A. K. \& Sulaiman, S. B. (2012). Project variables in performance of the project planning, implementation and controlling Processes. International Journal of Engineering and Innovative Technology (IJEIT) 1(3), Pp 254-268.

xix. Kakhbod, A. (2013). Resource allocation in decentralized systems with agents. Springer science business media, New York. Pp 5-14.

xx. Koskela, L. \& Howell, G. (2008). Reforming project management: the role of planning, execution and controlling.

xxi. Koskela, L. (2000). An exploration towards a production theory and its application to construction. Espoo, VTT Building Technology. 296 p. VTT Publications; 408

xxii. Mailu S.K., Wachira M.A., Munyasi J.W., Nzioka M., Kibiru S.K., Mwangi D.M., Kaguthi P., Kithome J. \& Marrero, C. M. A. (2014). Influence of prices on market participation decisions of indigenous poultry farmers in four districts of eastern province, Kenya. Journal of agriculture and social research (JASR) 12(1), 1-10.

xxiii. Magothe, T. M., Okeno, T. O., Muhuyi, W. B. \& Kahi, A. K. (2012) Indigenous chicken production in Kenya: Current status. World's Poultry Science Journal. 68: 119-132.

xxiv. Maskin, E. and Sj'str6m, T. (2002). Implementation theory. Handbook of Social Choice and Welfare, Volume 1, Edited by K.J Arrow, A.K. Sen and K. Suzumura. (2002 Elsevier Science B. V 
xxv. Moreki, J. C, R. Dikeme \& B. Poroga, (2010). The role of village poultry in food security and HIV/ AIDS mitigation in Chobe District of Botswana. Livestock Res. Rural Dev., 22(5),

xxvi. Muchadeyi, F.C., Wollny, C. B. A., Eding, H., Weigend, S., Makuza, S. M. \& Simianer, H. (2007). Variation in village chicken production system among agro-ecological zones of Zimbabwe. Tropical animal health and production; 39(6), 453-461.

xxvii. Mutombo P. K. (2014). An assessment of natural and socio- economic impacts on indigenous chicken production: A case study of Katangi and Ikombe divisions of Yatta sub county, Machakos County. Unpublished Master thesis.

xxviii. Nduthu P.W. (2015). Technological influence on implementation of indigenous poultry production project in Kenya; A case of Machakos indigenous poultry: international journal of contemporary applied sciences. 2 (5), 141-163.

xxix. Nganga, S. G. \& Amuhaya, M. I. (2013). Management in Implementation of Government Sponsored Projects in Kenya: A Survey OF Fish Ponds Projects in Gatundu South District- Kenya. International Journal of Academic Research in Business and Social Sciences, 3 (11), 101-116.

xxx. Ochieng, J., Owuor, G. \& Bebe, B. O. (2013). Management practices and challenges in smallholder indigenous chicken production in Western Kenya. Journal of Agriculture and Rural Development in the Tropics and Subtropics, 114(1), $51-58$.

xxxi. Okeno, T. O., Kahi, A. K. \& Peters, J. K. (2012) Characterization of Indigenous Chicken Production Systems in Kenya. Tropical Animal Health and Production. 44:601-608.

xxxii. Padhi, M. K. (2016). Importance of indigenous chicken for rural economy and their improvements for higher production performance. Cairo Scientific Journal; 2016 (1-9)

xxxiii. Patzak, G., (2009). Project Management Paradigm: A System Oriented Model of Project Planning, in Dimensions of Project Management, edited by Reschke, H. \& Schelle, H. Springer-Verlag, Berlin; 8(9), Pp 26-27.

xxxiv. Pearse, N. (2011). Deciding on the Scale Granularity of Response Categories of Likert type

xxxv. Pinto, J. K. and Slevin, D. P. (1989). In the project life cycle. Journal of project management. 14(1), 518-528

xxxvi. Reilly, E. T. (2007). How to build a high-performance organization. American Management Association.

xxxvii. Sarkar, K. \& Golam, M. (2009). A move from subsistence to semi commercial family poultry farming with local chickens; effective strategies for family poultry in Bangladesh. World's Poultry Science Journal; 65(2), pp.251-259.

xxxviii. Sathe, B. S. (2012). Planning and implementation of poultry projects in developing countries. World's poultry science association (India branch), Pune 411004, India. 12(2), 1-8.

xxxix. Sekaran U. (2003). Research Methods for Business - A Skill Building Approach. Wiley Publishers. 4th Edition

xl. Siyaya, B. J \& Masuku, M. B. (2013). Factors affecting commercialization of indigenous chickens in Swaziland. Journal of Agricultural Studies, 1(2), 86-101.

xli. Tabassum, F., Hoque, M. A., Islam, F., Ritchil, C. H., Faruque, M. O. \& Bhuiyan, A. K. F. H. (2014). Phenotypic and morphometric characterization of indigenous chickens at Jhenaigati Upazila of Sherpur district in Bangladesh. SAARC Journal of Agriculture; 12(2): Pp 154-169

xlii. Woollett, J. (2000), Innovate or Die - the Future for Project Management, Prosperity through Partnership. World Project Management Week. Incorporating Project Management Global Conference, AIPM (CD-Rom). 